\title{
Palavras do Prof. Luiz V. Décourt
}

\author{
(Pronunciado durante o Encontro dos \\ Discípulos do Prof. Zerbini)
}

Sinto-me tomado por profundo sentimento de dever: o da minha presença nesta sessão, que sucede à sua morte. Diante do doloroso acontecimento, aqui trago minha afirmação de que não desejaria outro neste local, a me substituir no alto privilégio deste depoimento.

Prof. Zerbini: o homem e o legado de sua Escola foi o tema escolhido para esta sessão; uma constelação de vidas na qual o trabalho de um foi, é e será a razão do trabalho de muitos.

Zerbini foi meu colega de turma e companheiro de estudos nos primeiros anos do curso médico em vivência muito próxima e afetuosa. Depois, acompanhei de perto a sua carreira até que, finalmente, unimos nossos esforços na tarefa comum de amparo aos cardiopatas.

Sua personalidade organizou-se sobre um tripé de caracteres: austeridade, capacidade de trabalho e busca de aprimoramento. Há homens que sonham mas não criam; há outros que procuram soluçōes sem o impulso inicial de idéias modeladoras, em tarefas monótonas e pouco expressivas; mas existem os mais credenciados que transformam em realidade os mais altos dos seus sonhos. Estes são os que formam e que criam, os que realmente marcam com obras os caminhos percorridos. Zerbini foi um destes. Um homem obsecado pelo trabalho, que tinha como sua a divisa do cardeal de Retz: Non sine labore, não sem trabalho.

Sempre o conheci como um profissional em busca do melhor, fazendo de cada hora uma oportunidade para novas conquistas. Procurou constantemente o aprimoramento de sua técnica operatória, comparando os próprios resultados com os de outros credenciados pela experiência e, mesmo, com os de alguns de seus assistentes, em setores altamente especializados. Esta atitude era uma regra nas reuniōes bissemanais de cardiologia pediátrica na qual se debatiam casos complexos de afecções congênitas.

Estimulou a criação de tipos de próteses valvares, programou experiências com a aparelhagem para circulação extracorpórea e manteve planos para sua melhor capacidade.

$\mathrm{Na}$ incessante busca de ação e de seu aperfeiçoamento os dias se sucediam quase sem momentos de repouso. Em suas próprias palavras não palmilhou campos paralelos de atividades, fossem elas literárias, artísticas ou de lazer. Ele as sentia como atração inexpressiva, perante o grande apelo do trabalho. E com este, plasmou sua forma de vida.

Dentre numerosas conquistas que enriqueceram sua carreira, desejo mencionar três, pelo que significaram e pelo que pude testemunhar.

A primeira foi a criação de equipe capacitada a enfrentar os desafios da cirurgia das afecçōes cardíacas. Inicialmente em intervenções que apenas representavam extensão da cirurgia geral e depois, desde a década de 50 , em operações com a alta técnica de céu aberto.

Senti, muito de perto, esses avanços e aqui trago um depoimento. Tendo conquistado a cátedra de Clinica Médica da Faculdade de Medicina da Universidade de São Paulo, procurei nela desenvolver, com especial carinho, a área de cardiologia. Recebi, então, vários pedidos de cirurgiões gerais para colaboração na terapêutica dos cardiopatas. E sempre os recusei. Eram, sem dúvida, homens aptos a intervençōes operatórias em seus setores, mas carentes da necessária experiência no campo especializado da cardiopatologia. Só algo mais tarde recebi, como oferta expressiva, a companhia de Zerbini. Não porque o via como colega de turma e grande amigo, mas porque acompanhara seu amplo exercício de preparo técnico: as viagens de estudos aos Estados Unidos, sempre programadas com lógica, e os trabalhos experimentais, em animais, sempre mais seguros. Não foi um improvisador, a só obter resultados mediocres depois de tentativas imprecisas e ineficientes - quando não nocivas - mas consciencioso cirurgião, a só realizar o que já se encontrava apto a realizar, com a segurança do trabalho preparatório e com credenciais para futuras conquistas. $E$, assim, criou suas equipes de ontem, de hoje e de sempre, capacitadas e respeitadas.

A segunda conquista que desejo aqui trazer foi a do transplante cardiaco. Por este lutamos juntos e também pude sentir, bem próximos, o seu entusiasmo e seu preparo técnico. $\mathrm{Na}$ época da intervenção pioneira de Barnard já possuia Zerbini boa experiência em 
estudos experimentais. Estes foram aprofundados e logo encontrou-se apto a intervenções no homem. Em período onde as dúvidas, as interrogações e até as críticas surgiam e se multiplicavam, manteve ele sua total confiança no futuro dos transplantes cardiacos. $\mathrm{E}$ - primeiro deles, na madrugada de 26 de maio de 1968 , exteriorizou uma técnica perfeita e segura. Só foi derrotado, alguns dias após, pelos fenômenos de incompatibilidade imunitária, não combativeis na época. Mas todos reconhecemos que sua intervenção, pioneira em nosso país, foi o estímulo para os sucessos ulteriores.

A terceira das grandes conquistas foi a criação do Instituto do Coração e nesta luta também avançamos juntos. Não há dúvida, entretanto, que sua foi a idéia original, mesmo quando o plano parecia utópico. E também, sua a crença inabalável no futuro da Instituição, quando determinados obstáculos pareciam intransponiveis. $E$ ainda vivem em meu espírito, permanentes, as recordações de momentos em que o meu próprio cepticismo, aparentemente bem fundamentado, foi combatido por sua certeza e sua confiança. Em companhia de alguns outros companheiros entre os quais Delmont Bittencourt, já falecido, participou de todos os planos da obra, desde a construção do prédio até as suas características funcionais, entendidas estas não apenas como atividades básicas mas também como tarefas complementares.

Essas três conquistas, expressivas e fecundas, definem o Professor e o Médico, em sua capacidade de sonhar, de realizar e de ensinar.

E em todos os setores a austeridade moral. Enfrentou eventuais crises e incompreensōes, mas nunca transigiu, nunca desceu a criticas pessoais, trazendo a sua resposta apenas pela integridade de atitudes.

Sempre respeitou o trabalho e o trabalhador, sem preferências e sem proteções comprometedoras. Sempre trouxe seu auxílio aos merecedores de seu aplauso e nunca os confundiu com os lisonjeadores. Nunca faltou aos necessitados, com a palavra e a ação.

Assim foi ele e assim é o legado à sua Escola. Recebeu discipulos de todo o Brasil e de vários locais do Exterior. E a eles deixou o seu tríplice exemplo.
Em primeiro lugar o do valor do trabalho ininterrupto, vencedor de dificuldades, de incompreensões, de resistência, de omissões e de indiferença, e também de eventuais períodos de desânimo e de depressão. Sua afirmação, tantas vezes repetida de que "nada resiste ao trabalho", não era apenas frase de circunstância, ôca e vazia, mas uma advertência e um apelo aos seus discipulos.

Como segundo legado, a presença operante dos atos de aprimoramento e de criação. Como atividades de rotina na própria continuidade das atividades científicas e assistenciais, porque sabia que elas são alimentos que nutrem a personalidade do médico. Sua vida já teria sido um exemplo, e suficiente, pela própria categoria. Mas fui testemunha da freqüência com que estimulava companheiros e discípulos na busca do adequado amparo aos pacientes, na luta pelo progresso e por algo próximo à perfeição em todos os atos profissionais. $E$ ainda de sua intransigência diante do comodismo e da mediocridade.

O terceiro legado foi também alto e expressivo: 0 da elevada moral nos contactos com os enfermos e com a coletividade. Princípios superiores a quaisquer tentativas de comprometimento; que formaram o cerne de sua personalidade e que não deverão ser esquecidos mesmo pelos discípulos mais diretamente atraídos pelas conquistas.

Então, não apenas o Médico e o Professor, mas também o Líder. A sua liderança foi ocorrência natural, esperada, justificada e desejável. Ela se exerceu em todo o País e mesmo no Exterior, manifestando-se perante os colegas, os discipulos, os auxiliares. E, como decorrente de atos que nunca se apagaram, manteve-se atuante durante a sua vida e não desapareceu após sua morte.

Esta Reunião dos seus discípulos exterioriza sua presença e assegura a sua permanência.

Como colega, como amigo e como companheiro de lutas, agradeço o privilégio de trazer, com minhas palavras, algo que contribúa, mesmo que pouco, para o conhecimento do grande exemplo que foi sua vida. 